\section{Public Facilities in the City of Semarang from the Elderly Perception}

\author{
Sri Sumijati; Suparmi \\ Fakultas Psikologi \\ Universitas Katolik Soegijapranata-Semarang \\ email : asih@unika.ac.id; minuk@unika.ac.id
}

Journal PSIKODIMENSIA

Volume 19, No. 1,

Januari - Juni 2020

ISSN cetak : 1411-6073

ISSN online : 2579-6321

DOI:10.24167/psidim.v19i1.2318

\begin{abstract}
The purpose of this study was to determine the perception of the elderly about public facilities in Semarang on four aspects, namely public buildings, hospitals, roadways and public transportations. Forty eight elderly range from 60 to 90 years old agree to become our respondents. Data collected by structured interview and analized quantitatively as well as qualitatively. In general this research shown that no contrast difference between positive and negative perception. Data analysis found that (1) the hospital was perceived to be the most positive, followed by public buildings, public transportations and roadways, (2) most of the subjects perceived the hospital's facilities were quite good, where information service was the best sub-aspects, (3) in related to public transportation the city buses are better than angkot. We suggest to the government to make Semarang a friendly city for the elderly, especially in improving the pavement and trans bus stops, public transportation driver behavior, and making it easier to register online at hospitals.
\end{abstract}

Key words : elderly, perception, public facilities

\section{PENDAHULUAN}

Lanjut usia (lansia) adalah periode perkembangan terakhir dalam rentang kehidupan manusia, yang berlangsung sejak seorang individu memasuki usia 60 tahun (Kail \& Cavanaugh, 2013; Peraturan Menteri Pekerjaan Umum / Permen PU No 30 tahun 2006). Berkat kemajuan teknologi dan perawatan kesehatan yang semakin baik, usia harapan hidup manusia semakin meningkat, yang berakibat pada meningkatnya jumlah lansia dari tahun ke tahun (Hara, 2007; Kail \& Cavanaugh, 2013; Rooy, Mufune \& Amadhila; 2015). Peningkatkan jumlah warga lansia menimbulkan problem sosial, ekonomi dan politik (Kail \& Cavanaugh, 2013), terutama bila pemerintah tidak ada persiapan dan perencanaan yang matang dalam membuat program-program atau pelayanan untuk lansia.

Pada masa lansia, individu secara umum akan mengalami berbagai perubahan kondisi fisik yang berakibat pada penurunan kesehatan, kemampuan dan fungsi fisik dan psikomotorik, baik motorik halus maupun motorik kasar (Bjorklund \& Bee, 2009; Kail \& Cavanaugh, 2013). Adanya penurunan tersebut menyebabkan lansia rentan mengalami berbagai macam keterbatasan untuk melakukan mobilitas dan aktivitas sehari-hari (Papalia, Sterns, Feldman \& Camp, 2007). Lansia menjadi kurang sigap, tidak kuat berlari atau berjalan jauh, tidak mampu naik tangga, mudah terpeleset karena kaki sudah tidak kuat, ketajaman penglihatan dan pendengaran berkurang dan berbagai macam perubahan lain. Kondisi ini menyebabkan lansia seringkali disebut sebagai frail person atau orang yang lemah (Kail \& Cavanaugh, 2013), baik kelemahan fisik, kognitif maupun aspek psikologis lainnya. Oleh karena itu lansia membutuhkan kondisi maupun fasilitas lingkungan tertentu agar dapat terus beraktivitas secara mandiri, tanpa tergantung dengan orang lain, baik saat di 
rumah maupun ketika harus beraktivitas di luar rumah.

Adanya ruang dan fasilitas publik yang aman dan memungkinkan lansia untuk mandiri akan membahagiakan lansia karena mereka tidak harus tergantung kepada orang lain ketika beraktivitas di luar rumah (Wijayanti, 2015). Kemandirian pada lansia juga menimbulkan perasaan positif dan well being lansia (Haak, Fange, Iwarsson \& Ivanoff, 2007; Hara, 2007) dan juga berdampak secara positif pada orangorang yang ada di sekitar lansia, seperti anak dan cucu mereka (National Population \& Family Development, 2015). Lansia yang secara terus membutuhkan bantua orang lain membuat lansia merasa tidak berguna dan kehilangan harga dirinya (Wijayanti, 2015).

Namun kenyataannya, dari pengataman sehari-hari nampak bahwa berbagai fasilitas publik atau fasilitas publik yang ada di sekitar lansia seringkali tidak akomodatif untuk lansia. Hampir 30\% lansia merasa diabaikan atau tidak mendapatkan dukungan dari orang-orang disekitarnya (National Population \& Family Development, 2015). Ada banyak fasilitas tetapi hanya bisa digunakan oleh orang-orang muda dengan kekuatan fisik yang prima. Pemerintah seringkali tidak menunjukkan komitmen yang kuat terhadap lansia (Carol Yip, Star Metro 2015 dalam National Population \& Family Development, 2015). Masyarakat umumnya menunjukkan perjuangan yang kuat dalam membela anak dan binatang, dan itu hal yang bagus. Namun mengapa tidak melakukan hal yang sama baiknya pada lansia? Demikian pertanyaan kritis dari Lily Fu (Star Metro 2015 dalam National Population \& Family Development, 2015). Keterbatasan fasilitas publik yang bisa digunakan oleh lansia menyebabkan sebagian besar lansia menjadi tergantung kepada orang lain dalam melakukan aktivitas seharihari. Kemiskinan, ketidaktahuan, kekuatan fisik yang semakin menurun membuat lansia semakin menjadi warga yang terpinggirkan (Rooy, Mufune \& Amadhila, 2015). Fasilitas publik yang terdapat dalam masyarakat tidak ramah dengan lansia.

Dari pengamatan peneliti fasilitas publik yang ada di kota Semarang belum memperhatikan kebutuhan lansia. Misalnya, gedung-gedung layanan publik (misalnya kantor pemerintah, bank) seringkali berlantai licin, tidak menyediakan toilet duduk, toilet sempit sehingga tidak bisa diakses lansia berkursi roda. Rumah sakit melayani pendaftaran pasien melalui jalur online, lantai licin tanpa ada pegangan di tembok, papan informasi yang tidak terbaca lansia. Halte bus rapid trans (BRT, bus trans) lintasannya curam, pegangan di bus kota yang tinggi sehingga lansia kurang dapat meraih pegangan saat harus berdiri dalam bus, jalan raya yang lebar dan padat kendaraan tetapi tidak ada fasilitas penyeberangan jalan yang mudah diakses lansia. Angkutan kota (angkot) yang beratap pendek dan sempit sehingga menyulitkan lansia untuk masuk keluar, lantai angkot yang tinggi, angkot yang berhenti mendadak atau berjalan sebelum lansia duduk dengan baik atau turun dengan aman. Belum lagi trotoar yang berundak-undak, sebagian bahkan digunakan masyarakat untuk berjualan, tempat parkir, bengkel dst. Kondisi fasilitas publik yang tidak ramah lansia menyebabkan lansia rentan untuk mengalami kecelakaan-kecelakaan fisik atau harus tergantung kepada bantuan orang lain ketika berada di luar rumah.

Berdasarkan uraian tersebut di atas nampak adanya kesenjangan antara harapan dan kenyataan. Harapannya lansia mendapatkan kemudahan dengan adanya fasilitas publik sehingga memudahkan mobilitas lansia untuk secara mandiri melakukan berbagai aktivitas di luar rumah tanpa bantuan orang lain. Permen PU No 30 tahun 2006 dan Permen PU No 03 tahun 2014 sudah 
mengatur ketentuan-keterntuan yang ideal bagi fasilitas publik dan mencantumkan pula aturan terkait dengan pengguna dari kalangan difabel (termasuk lansia), meskipun dalam kenyataan ketentuan yang ideal tersebut belum tentu dilaksanakan dalam pembangunan dan penyediaan fasilitas publik. Namun kenyataannya, belum semua fasiltas umum yang dibangun oleh pemerintah bisa diakses oleh lansia. Hal ini semakin diperberat dengan kurangnya koordinasi antar instansi yang terkait, terutama antara kementrian kesehatan, transportasi dan dinas pekerjaan umum. Fasiltas umum pada lansia membutuhkan kerjasama berbagai pihak (Lily Fu dalam National Population \& Family Development, 2015).

Proses persepsi didahului oleh diterimanya stimulus oleh indra manusia, yang menghasilkan gambaran tentang objek. Stimulus yang diterima kemudian diolah sehingga akhirnya menjadi informasi yang bermakna, dipahami dan diterima oleh struktur kognisi individu yang bersangkutan (Kail \& Cavanaugh, 2013; William, 2017). Fasilitas publik adalah semua atau sebagian dari kelengkapan prasarana dan sarana yang dapat digunakan atau dimanfaatkan oleh banyak orang, rakyat atau masyarakat umum (Echols \& Shadily, 2016; Permen PU No 30 tahun 2006; Suharso \& Retnoningsih, 2011). Secara ringkas ada empat aspek fasilitas publik yang dijadikan sebagai objek persepsi lansia, yaitu aspek gedung layanan publik (meliputi kantor pemerintah dari kota sampai kelurahan, kantor-kantor instansi), aspek rumah sakit dan fasilitas kesehatan lainnya (meliputi rumah sakit pemerintah maupun swasta, puskesmas), aspek transportasi umum (meliputi bus kota/bus trans dan angkot) dan aspek jalan raya.

\section{METODE}

Metode penelitian menggunakan kombinasi antara kualitatif dan kuantitatif (Fontana \& Frey, 2009; Johnson \& Turner, 2010). Data penelitian diungkap melalui wawancara terstruktur secara individual, dimana subjek diberi pertanyaan seputar penilaian mereka terhadap fasilitas publik di Kota Semarang yang meliputi empat aspek, yaitu gedung layanan publik, rumah sakit, transportasi dan jalan raya. Empatpuluh delapan lansia berusia 60-90 tahun terlibat dalam penelitian ini. Mereka adalah lansia laki-laki dan perempuan pengguna fasilitas publik yang berdomisili di wilayah Kota Semarang dan sekitarnya.

\section{HASIL}

Persepsi terhadap Fasilitas Publik Secara Umum. Berdasarkan komentar umum yang diberikan, pandangan subjek terhadap fasilitas publik di Kota Semarang berimbang antara yang mengatakan baik dan buruk (52\% vs 48\%). Namun bila dilihat setiap aspek nampak bahwa pada keempat fasilitas publik, subjek yang mengatakan bahwa fasilitas sudah baik lebih banyak dari pada yang mengatakan buruk.

Tabel 1. Persepsi terhadap Fasilitas Publik Secara Umum

\begin{tabular}{lcc}
\hline \multicolumn{1}{c}{ Aspek } & Baik\% & Buruk\% \\
\hline Gedung & 84.9 & 15.1 \\
\hline Rumah Sakit & 86.9 & 13.1 \\
\hline Jalan Raya & 63.2 & 36.8 \\
\hline Transportasi umum & 71.3 & 28.7 \\
\hline persepsi secara umum & 52 & 48 \\
\hline
\end{tabular}


Persepsi terhadap Gedung Layanan Publik. Sebagian besar subjek (84.9\%) menganggap bahwa fasilitas yang ada di gedung layanan publik umumnya sudah baik, dan hanya sedikit (15.1\%) yang menganggap masih buruk. Dari subaspek gedung yang dikatakan baik lokasi kantor, kondisi lantai, dan ruang tunggu secara berturut-turut merupakan tiga teratas fasilitas yang paling banyak dikatakan baik, sedangkan toilet, papan petunjuk dan peta gedung merupakan tiga peringkat baik terendah. Data selengkapnya dapat dilihat pada Tabel 2.

Tabel 2. Persepsi terhadap Gedung Layanan Publik

\begin{tabular}{lccccc}
\hline \multicolumn{1}{c}{ Aspek } & \multicolumn{2}{c}{ Baik } & \multicolumn{2}{c}{ Buruk } & Tidak merespon \\
\hline Lokasi Kantor & 42 & 93.3 & 3 & 6.7 & \\
\hline Lantai & 42 & 91.3 & 4 & 8.7 & 2 \\
\hline Ruang Tunggu & 40 & 88.8 & 5 & 11.2 & 3 \\
\hline Informasi & 38 & 86.3 & 6 & 13.7 & 4 \\
\hline Bertingkat & 31 & 86.1 & 5 & 13.9 & 12 \\
\hline Parkir & 38 & 84.4 & 7 & 15.6 & 3 \\
\hline Satpam & 36 & 81.8 & 8 & 18.2 & 4 \\
\hline Toilet & 29 & 80.5 & 7 & 19.5 & 12 \\
\hline Papan Petunjuk & 36 & 80 & 9 & 20 & 3 \\
\hline Peta & 29 & 76.3 & 9 & 23.7 & 10 \\
\hline Rerata & & 84.9 & & 15.1 & \\
\hline
\end{tabular}

Persepsi terhadap Rumah Sakit dan Fasilitas Kesehatan lainnya. Data yang tersaji dalam laporan di bagian ini lebih menekankan pada fasilitas fisik yang ada di rumah sakit/fasilitas kesehatan lainnya, dan tidak termasuk layanan medis (dari dokter dan perawat) dan layanan perawatan pasien lainnya. Tabel 3 menunjukkan sebagian besar subjek penelitian (86.9\%) mempersepsi bahwa fasilitas yang ada di rumah sakit atau fasilitas kesehatan lainnya sudah baik.
Ada tiga sub-aspek yang mendapatkan respon baik teratas secara berturut-turut, yaitu informasi, kondisi lantai, dan lokasi, sedangkan ruang tunggu, parkir dan pegangan berada pada peringkat terendah. Sejumlah $26.7 \%$ subjek merespon buruk tentang fasilitas pegangan di tembok rumah sakit dan semuanya mengatakan tidak ada pegangan atau tidak pernah melihat ada pegangan di tembok.

Tabel 3. Persepsi terhadap Rumah Sakit dan Fasilitas Kesehatan Lain

\begin{tabular}{lccccc}
\hline \multicolumn{1}{c}{ Aspek } & \multicolumn{2}{c}{ Baik } & \multicolumn{2}{c}{ Buruk } & Tidak merespon \\
\hline Informasi & Jumlah & $\%$ & Jumlah & $\%$ & \\
\hline Lantai & 45 & 95.7 & 2 & 4.3 & 1 \\
\hline Lokasi & 44 & 93.6 & 3 & 6.4 & 1 \\
\hline Petunjuk & 44 & 91.6 & 4 & 8.4 & - \\
\hline Bertingkat & 43 & 91.5 & 4 & 8.5 & 1 \\
\hline Toilet & 38 & 90.4 & 4 & 9.6 & 6 \\
\hline Satpam & 38 & 86.4 & 6 & 13.6 & 4 \\
\hline Peta & 38 & 86.4 & 6 & 13.6 & 4 \\
\hline Ruang Tunggu & 38 & 84.4 & 7 & 15.6 & 3 \\
\hline Parkir & 36 & 81.8 & 8 & 18.2 & 4 \\
\hline Pegangan & 39 & 81.2 & 9 & 18.8 & - \\
\hline Rerata & 33 & 73.3 & 12 & 26.7 & 3 \\
\hline
\end{tabular}


Persepsi terhadap Fasilitas Jalan Raya. Jalan raya yang dipersepsi oleh subjek penelitian meliputi jalan raya utama dan jalan raya pendukung. Hampir semua jalan raya utama di kota Semarang masuk dalam daftar jalan raya yang dipersepsi. Dari keempat aspek yang dipersepsi lansia, persepsi tentang jalan raya menunjukkan fenomena yang berbeda karena komposisi penilaian "baik" dan "buruk"nya relatif tidak terlalu mencolok (seperti yang nampak pada Tabel 4) bila dibandingkan dengan persepsi terhadap ketiga aspek lainnya, yaitu $63.2 \%$ vs $36.8 \%$. Dengan demikian para lansia subjek penelitian ini cukup banyak melihat dan mengalami hal-hal yang negatif tentang fasilitas jalan raya, sehingga muncul persepsi yang buruk. Hal ini nampak dari respon yang diberikan subjek.

Tabel 4. Persepsi terhadap Fasilitas Jalan Raya

\begin{tabular}{lccccc}
\hline \multicolumn{1}{c}{ Aspek } & \multicolumn{2}{c}{ Baik } & \multicolumn{2}{c}{ Buruk } & Tidak merespon \\
\hline & Jumlah & $\%$ & Jumlah & $\%$ & \\
\hline Fisik jalan & 37 & 80.4 & 9 & 19.6 & 2 \\
\hline Penerangan & 32 & 66.6 & 16 & 33.4 & - \\
\hline Rambu & 31 & 65.9 & 16 & 34.1 & 1 \\
\hline Lebar jalan & 26 & 54.1 & 22 & 45.9 & - \\
\hline Trotoir & 23 & 48.9 & 24 & 51.1 & 1 \\
\hline Rerata & 63.2 & & 36.8 & \\
\hline
\end{tabular}

\section{Persepsi terhadap Transportasi}

Umum. Di kota Semarang hanya ada dua jenis transportasi umum, yaitu bus trans dan angkutan kota (angkot). Dibandingkan dengan angkot, bus trans lebih banyak dinilai baik oleh subjek. Tabel 5 menunjukkan bahwa yang menilai bus trans baik ada 35 orang, sedangkan angkot hanya dinilai baik oleh 29 orang. Dengan demikian yang menilai angkot buruk juga lebih banyak (17 orang) daripada yang menilai bus trans buruk (9 orang). Hal ini menunjukkan bahwa para lansia menganggap bahwa angkot yang ada di kota Semarang ini masih memiliki banyak kekurangan.

Tabel 5. Persepsi terhadap Transportasi Umum

\begin{tabular}{lccccc}
\hline \multicolumn{1}{c}{ Aspek } & \multicolumn{2}{c}{ Baik } & \multicolumn{2}{c}{ Buruk } & Tidak merespon \\
\hline & Jumlah & $\%$ & Jumlah & $\%$ & \\
\hline Bus & 35 & 79.5 & 9 & 20.5 & 4 \\
\hline Angkot & 29 & 63.1 & 17 & 36.9 & 2 \\
\hline Rerata & & 71.3 & & 28.7 & \\
\hline
\end{tabular}

Analisis data kualitatif menunjukkan hasil yang tidak jauh berbeda dengan data kuantitatif. Analisis secara kuantitatif deskriptif terhadap data menunjukkan hasil bahwa secara umum persepsi positif secara berturut-turut dari yang paling tinggi adalah persepsi terhadap rumah sakit (62,63\%) kemudian gedung (62,07\%). Persepsi negatif secara berturut-turut dari yang paling tinggi yaitu jalan raya $(67,37 \%)$ kemudian transportasi umum (52,78\%).
Berkaitan dengan jenis transportasi umum, bus trans lebih banyak dinilai secara positif $(28,47 \%)$ daripada angkot (13,89\%).

Analisis kuantitatif deskriptif juga dilakukan terhadap setiap aspek fasilitas publik. Aspek gedung yang dipersepsikan paling positif adalah letak kantor (8,28\%), ditunjukkan dengan jawaban "letak kantor baik ditengah kota”, “mudah dijangkau”, "strategis", "dilewati angkutan umum”, "lokasi 
mudah dijangkau". Aspek gedung berikutnya yang dinilai secara positif adalah layanan informasi (7,59\%) ditunjukkan dengan jawaban "ada loket di layanan informasi”, "layanan informasi ada", "informasi mudah ditemukan”, "ada resepsionis”, "informasi jelas”, "petugasnya ramah”, "layanan informasi baik", "tidak mempersulit”, "bicara baik". Hasil secara terinci pada Tabel 6 .

Tabel 6. Persepsi Positif Terhadap Gedung

\begin{tabular}{lcc}
\hline \multicolumn{1}{c}{ Aspek Gedung } & Frekuensi & Persentase(\%) \\
\hline Letak Kantor & 12 & 8,28 \\
Layanan Informasi & 11 & 7,59 \\
Fasilitas/Pelayanan & 10 & 6,89 \\
Papan Petunjuk & 9 & 6,21 \\
Ruang Tunggu & 8 & 5,52 \\
Tempat Parkir & 8 & 5,52 \\
Toilet & 7 & 4,83 \\
Satpam & 7 & 4,83 \\
Gedung Bertingkat & 7 & 4,83 \\
Lantai & 6 & 4,14 \\
Pelayanan & 4 & 2,76 \\
Pegangan & 1 & 0,69 \\
\hline
\end{tabular}

Persepsi negatif terhadap gedung dengan persentase dua tertinggi adalah papan petunjuk $(7,64 \%)$ dan tempat parkir (5,56\%). Respon negatif terhadap papan petunjuk muncul dengan jawaban " tidak ada peta kantor", "peta kantor tidak jelas”, “tidak ada papan petunjuk”, “gak paham petanya”, "papan petunjuk tulisannya susah dibaca”, "papan petunjuk tulisannya kecil”, “tidak ada papan petunjuk arah atau peta gedung”. Tempat parkir juga dinilai secara negatif oleh subjek, muncul dengan respon "tempat parkirnya sempit", "tidak ada petugasnya”, "parkirnya di pinggir jalan”, "tempat parkirnya panas". Hasil secara detail terdapat pada Tabel 7 .

Tabel 7.Persepsi Negatif Terhadap Gedung

\begin{tabular}{lcc}
\hline \multicolumn{1}{c}{ Aspek Gedung } & Frekuensi & Persentase(\%) \\
\hline Papan Petunjuk & 11 & 7,59 \\
Tempat Parkir & 8 & 5,52 \\
Toilet & 7 & 4,83 \\
Gedung Bertingkat & 6 & 4,14 \\
Layanan Informasi & 6 & 4,14 \\
Satpam & 5 & 3,45 \\
Letak Kantor & 4 & 2,76 \\
Ruang Tunggu & 4 & 2,76 \\
Lantai & 2 & 1,38 \\
Pegangan & 2 & 1,38 \\
\hline
\end{tabular}

Tiga aspek rumah sakit yang mendapatkan penilaian positif adalah layanan informasi (8,59\%), toilet $(8,08 \%)$ dan fasilitas gedung bertingkat (6,57\%). Aspek yang mendapatkan persepsi negatif dengan peringkat empat besar yaitu pendaftaran (6,57\%), pelayanan (5,56\%), papan penunjuk (5,05\%) dan tempat parkir (5,05\%). Hasil secara terinci persepsi setiap aspek rumah sakit bisa dilihat pada Tabel 8 dan Tabel 9. 
Dari Tabel 8 bisa dilihat bahwa persepsi positif terhadap layanan informasi rumah sakit ditunjukkan dengan jawaban subjek yang mengatakan “ informasi ada”, "informasi jelas dan mudah ditemukan", "informasi diberikan dengan jelas", "papan informasi mudah ditemukan, jelas", "ada petugas yang menjelaskan". Aspek toilet yang mendapatkan penilaian positif nampak dari jawaban "kamar mandi lengkap", "toilet bersih", "ada closet duduk", "toiletnya terang", "ada closet duduk dan ada yang jongkok". Aspek rumah sakit berikutnya yang mendapatkan penilaian positif tiga besar yaitu gedung bertingkat, dengan respon "ada trap”, “tangga nyaman”, "ada lift”.

Tabel 8. Persepsi Positif Terhadap Rumah Sakit

\begin{tabular}{lcc}
\hline Aspek Rumah Sakit & Frekuensi & Persentase(\%) \\
\hline Layanan Informasi & 17 & 8,59 \\
Toilet & 16 & 8.08 \\
Gedung Bertingkat & 13 & 6,57 \\
Baik & 12 & 6,06 \\
Papan Penunjuk & 11 & 5,56 \\
Satpam & 11 & 5,56 \\
Lantai & 10 & 5,05 \\
Pelayanan & 9 & 4,55 \\
Tempat Parkir & 7 & 3,54 \\
Letak Rumah Sakit & 6 & 3,03 \\
Pegangan & 4 & 2,02 \\
Ruang Tunggu & 4 & 2,02 \\
Pendaftaran & 3 & 1,52 \\
Keamanan & 1 & 0,51 \\
\hline
\end{tabular}

Dari Tabel 9 dapat dilihat bahwa aspek persepsi negatif terhadap rumah sakit dengan persentase tertinggi adalah pendaftaran.

Hal ini muncul dari respon subjek yang mengatakan "tidak paham pendaftaran online harus antri sejak pagi”, "pendaftaran buruk", "harus antre lama, tidak dapat kuota nomor", "keluarga tentara lebih diutamakan", "ada pembatasan kuota pasien”, "pendafataran lama", "pasien sulit mendaftar online", "di puskesmas tidak ada pendaftaran online", "saat pendaftaran harus dibantu anak karena tidak paham online", "pendaftaran harus datang sendiri". Aspek berikutnya yang dinilai negatif adalah pelayanan.

Respon yang dimunculkan antara lain "obatnya itu-itu saja, lama sembuhnya", "bila di rumah sakit tidak ada obatnya maka pasien harus cari sendiri di luar rumah sakit", "bila obat melebih batas harus bayar sendiri", "saat mau opname sering tidak ada kamar", "lama layanannya, harus antri dari pagi sampai sore” 
Tabel 9. Persepsi Negatif Terhadap Rumah Sakit

\begin{tabular}{lcc}
\hline \multicolumn{1}{c}{ Aspek Rumah Sakit } & Frekuensi & Persentase(\%) \\
\hline Pendaftaran & 13 & 17.56 \\
Pelayanan & 11 & 14.86 \\
Papan Petunjuk & 10 & 13.51 \\
Tempat Parkir & 10 & 13.51 \\
Ruang Tunggu & 9 & 12.16 \\
Pegangan & 6 & 8.10 \\
Toilet & 4 & 5.40 \\
Kebersihan & 3 & 4.04 \\
Satpam & 3 & 4.04 \\
Letak Rumah Sakit & 2 & 2.70 \\
Gedung Bertingkat & 2 & 2.70 \\
Layanan Informasi & 1 & 1.35 \\
\end{tabular}

Secara umum, persepsi terhadap jalan raya menunjukkan persentase yang lebih besar pada persepsi negatif $(67,03 \%)$ daripada persepsi positif (31,97\%). Hasil secara terinci tentang setiap aspek jalan raya bisa dicermati dalam Tabel 10 dan 11. Dari Tabel 10 dapat dilihat bahwa tiga besar aspek jalan raya yang dinilai positif adalah kemudahan menyeberang (5,95\%), trotoar $(5,41 \%)$ dan rambu lalu lintas $(5,41 \%)$.

Persepsi positif terhadap kemudahan menyeberang dikuatkan dengan jawaban subjek yang mengatakan "ada zebra cross", "ada jembatan penyeberangan”, “jalan mudah diseberangi”, "kemudahan menyeberang", "ada petugas yang menyeberangkan”. Respon positif terhadap jalan raya juga muncul pada aspek trotoar, antara lain dengan ungkapan "trotoar lebar", "di trotoar ada tempat duduk untuk istirahat”, "trotoar nyaman dilewati, tidak licin, tidak naik turun”, "trotoar cukup lebar”, “ada trotoar”. Rambu lalu lintas mendapatkan penilaian positif, yaitu dengan ungkapan "rambu lalu lintas jelas", "di lampu merah ada timer-nya", "rambu lalu lintas menyala dengan jelas", "rambu lalu lintas ada”, "ada kaca spion besar”, "rambu mudah terlihat"

Tabel 10. Persepsi Positif Terhadap Jalan Raya

\begin{tabular}{lcc}
\hline \multicolumn{1}{c}{ Aspek Jalan Raya } & Frekuensi & Persentase(\%) \\
\hline Kemudahan Menyeberang & 11 & 5,95 \\
Trotoar & 10 & 5,41 \\
Rambu & 10 & 5,41 \\
Fisik Jalan & 9 & 4,87 \\
Peneranagan & 7 & 3,78 \\
Baik & 6 & 3,24 \\
Penyekat Jalan & 3 & 1,62 \\
Petugas & 3 & 1,62 \\
Kelancaran & 1 & 0,54 \\
Papan Penunjuk Jalan & 1 & 0,54 \\
\hline
\end{tabular}

Sebagian besar subjek

kondisi jalan raya di Semarang (67,03\%). menunjukkan persepsi negatif terhadap Aspek jalan raya yang dinilai secara 
negatif dengan persentase terbesar adalah aspek trotoar (12,43\%), kemudahan menyeberang $(10,27 \%)$ dan fisik jalan $(10,27 \%)$. Respon negatif terhadap trotoar muncul dengan ungkapan "trotoar panas", "trotoar sempit”, "trotoar terhalang warung atau tertutup halte bus", "trotoar tidak rata, naik turun", "tidak ada tempat duduk untuk istirahat", "tidak ada trotoar", "trotoar hanya ada di beberapa lokasi”, "trotoar bagus tapi suka licin”, "jalur buat tuna netra di trotoar tidak dibuat serius, nabrak pot”. Fisik jalan dipersepsi secara negatif oleh subjek dengan pernyataan "jalan bergelombang, pernah tersandung”, "pinggir jalan becek", "masih ada jalan berlubang”, "jalan njeglong-njeglong", jalan naik turun dan sempit”, "jalan rusak parah”.

Penilaian terhadap transportasi umum merupakan persepsi subjek terhadap transportasi umum yang ada di Kota Semarang. Ada subjek yang mempersepsi bus trans (54,17\%), angkot $(38,19)$ dan ada pula subjek yang menyamakan antara angkot dan bus trans (7,74\%). Data kualitatif secara umum menunjukkan bahwa persentase persepsi negatif (52,78\%) subjek menunjukkan persentase yang lebih tinggi daripada persentase persepsi positif (47,22\%). Hasil secara terinci tentang persepsi terhadap aspek-aspek transportasi umum terdapat dalam Tabel 12 dan Tabel 13.

Tabel 11. Persepsi Negatif Terhadap Jalan Raya

\begin{tabular}{lcc}
\hline \multicolumn{1}{c}{ Aspek Jalan Raya } & Frekuensi & Persentase(\%) \\
\hline Trotoar & 23 & 12,43 \\
Kemudahan Menyeberang & 19 & 10,27 \\
Fisik Jalan & 19 & 10,27 \\
Penerangan & 18 & 9,73 \\
Rambu & 13 & 7,03 \\
Kelancaran & 10 & 5,41 \\
Petugas & 8 & 4,32 \\
Kemananan & 7 & 3,78 \\
Penyekat Jalan & 3 & 1,62 \\
Halte & 1 & 0,54 \\
Taman & 1 & 0,54 \\
Parkir & 1 & 0,54 \\
\hline
\end{tabular}

Dari Tabel 12 dapat dilihat bahwa persepsi positif secara berturut-turut dari yang paling tinggi adalah persepsi terhadap bus trans $(28,47 \%)$, angkot $(13,89 \%)$, dan angkot/bus trans $(4,86 \%)$. Aspek bus trans yang mendapatkan persentase tiga besar adalah halte, pelayanan, tarif dan pegangan; sedangkan aspek angkot yang mendapatkan persentase dua besar nilai positif adalah tarif dan perilaku sopir. Persepsi positif terhadap halte ditunjukkan dengan jawaban subjek yang mengatakan "ada halte", "halte ada atapnya dan ada tempat duduknya", pelayanan ditunjukkan dengan ungkapan "kondektur mau mencarikan tempat duduk", "ada pemandu, ada petugas yang mencarikan tempat duduk". Tarif bus trans juga dinilai sebagai aspek yang positif oleh beberapa subjek, dengan respon "harga terjangkau", "tarif murah", ”tarif terjangkau”. 
Tabel 12. Persepsi Positif Terhadap Transportasi Umum

\begin{tabular}{lcclccccc}
\hline \multicolumn{2}{c}{ Bus Trans (28,47\%) } & \multicolumn{3}{c}{ Angkot (13,89\%) } & \multicolumn{3}{c}{$\begin{array}{c}\text { Bus Trans \& Angkot } \\
(4,86 \%)\end{array}$} \\
\hline \multicolumn{1}{c}{ Aspek } & F & \% & \multicolumn{1}{c}{ Aspek } & F & $\%$ & Aspek & F & $\%$ \\
\hline Halte & 10 & 6,94 & Tarif & 9 & 6,25 & Baik & 7 & 4,86 \\
Pelayanan & 6 & 4,17 & Perilaku Sopir & 8 & 5,56 & & & \\
Tarif & 5 & 3,47 & Kondisi Angkutan & 2 & 1,39 & & \\
Pegangan & 5 & 3,47 & Pelayanan & 1 & 0,69 & & \\
Tempat Duduk & 4 & 2,78 & & & & & \\
Kenyamanan & 4 & 2,78 & & & & & & \\
Informasi & 3 & 2,08 & & & & & & \\
Tangga & 2 & 1,39 & & & & & & \\
Fasilitas Baik & 2 & 0,69 & & & & & & \\
Baik & 1 & 0,69 & & & & & & \\
\hline
\end{tabular}

Keterangan: $\mathrm{F}=$ Frekuensi

Secara umum subjek menilai transportasi umum secara negatif, baik untuk bus trans $(25,69 \%)$ maupun angkot (24,31\%). Halte pada satu sisi merupakan aspek yang mendapatkan penilaian positif paling tinggi, tetapi pada saat yang bersamaan juga dinilai secara negatif. Halte mendapatkan persentase penilaian negatif yang paling tinggi $(11,11 \%)$, sedangkan aspek angkot yang dinilai paling negatif adalah perilaku sopir $(13,89 \%)$. Secara detail data bisa dilihat dalam Tabel 13.

Halte dinilai secara negatif muncul dari ungkapan subjek yang mengatakan "kursi roda susah naik turun halte", "jumlah tempat duduknya sedikit”, "halte sempit, tidak luas, tidak ada tempat duduk", "halte tidak permanen hanya tangga”, "halte jauh-jauh", "halte susah untuk kursi roda", halte menyulitkan orang dengan keterbatasan fisik", "halte sulit untuk lansia, jaraknya jauh-jauh”, "jarak antar halte menyulitkan orang dengan kesulitan fisik", antara halte dan bus pijakannya kurang rata”, "tangga bus dan halte tidak rata", "halte lintasannya curam”, "banyak halte yang sudah rusak"

Dibandingkan dengan persepsi negatif terhadap halte, maka penilaian negatif pada aspek lain dari bus trans relatif rendah, yaitu berkisar antara 0,69 $\%$ sampai $2,08 \%$, seperti terlihat pada Tabel 13. Perilaku sopir bus trans yang dinilai negatif yaitu perilaku sopir yang "sering mengerem mendadak", "berhenti jauh dari halte", "bus kurang mepet dengan halte”.

Persepsi negatif pada angkot paling banyak disebabkan oleh perilaku sopir. Hal ini muncul dengan ungkapan subjek yang mengatakan " sopir tidak sabaran”, "sering ngetem", "sering ngerem mendadak", "ngetem lama”, "terlalu lama jalannya”," jalannya pelanpelan, nyari penumpang", "berhenti di sembarang tempat”, "sopir ugal-ugalan”, "sopir main HP”, "suka ngebut", "mobil sudah jalan padahal penumpang belum duduk”. 
Tabel 13. Persepsi Negatif terhadap Transportasi Umum

\begin{tabular}{lcclccccc}
\hline \multicolumn{3}{c}{ Bus Trans } & \multicolumn{3}{c}{ Angkot } & \multicolumn{3}{c}{ Bus Trans \& Angkot } \\
\hline Aspek & F & $\%$ & Aspek & F & $\%$ & Aspek & F & $\%$ \\
\hline Halte & 1 & & & 2 & & & & \\
Perilaku Sopir & 6 & 11,11 & Perilaku Sopir & 0 & 13,89 & Perilaku Sopir & 2 & 1,39 \\
Fasilitas & 3 & 2,08 & Pelayanan & 4 & 2,78 & Pelayanan & 1 & 0,69 \\
Pelayanan & 3 & 2,08 & Kenyamanan & 3 & 2,08 & Kenyamanan & 1 & 0,69 \\
Pegangan & 3 & 2,08 & Keamanan & 3 & 2,08 & & & \\
Tempat Duduk & 3 & 2,08 & Kondisi & 3 & 2,08 & & & \\
Khusus & 2 & 1,39 & Tarif & 2 & 1,39 & & \\
Kemananan & 2 & 1,39 & & & & & & \\
Tangga & 2 & 1,39 & & & & & \\
$\begin{array}{l}\text { Pijakan Bus } \\
\text { Tinggi }\end{array}$ & 1 & 0,69 & & & & & \\
Informasi & 1 & 0,69 & & & & & \\
Tempat & & & & & & & \\
Terpisah & 1 & 0,69 & & & & & \\
\hline
\end{tabular}

Keterangan: $\mathrm{F}=$ Frekuensi

Kenyamanan angkot dinilai negatif, dikuatkan dengan ungkapan subjek yang mengatakan "atap pendek", "angkot sempit sehingga susah keluar", "sumpek", "sempit”. Keamanan juga dinilai negatif, muncul dengan respon "kadang ada penumpang yang nggandul”, "ada gendam dalam angkot" , sedangkan berkaitan dengan tarif yang dinilai negatif adalah "tarif yang tidak pasti”. Kondisi angkot juga dinilai oleh beberapa subjek dengan negatif, yaitu "mobilnya tua, ada yang jelek", "rusak fasilitasnya", "tidak ada pintunya “. Ringkasan bisa dilihat dalam Tabel 13.

\section{DISKUSI}

Tujuan penelitian ini adalah untuk mengetahui persepsi lansia tentang fasilitas publik di Kota Semarang, yang meliputi pemahaman tentang jenis fasilitas publik, hambatan yang dirasakan dalam menggunakan fasilitas publik dan fasilitas publik seperti apa yang mereka butuhkan. Kail \& Cavanaugh (2013) mengatakan bahwa persepsi adalah suatu proses dimana otak menerima, menyeleksi, memodifikasi dan mengorganisasi rangsangan-rangsangan yang diterima, yang merupakan hasil dari stimulasi fisik. Persepsi menghasilkan gambaran tentang suatu objek yang diperoleh dari stimulasi pada sistem sensori (William, 2017). Definisi ini mengindikasikan bahwa persepsi seseorang terhadap sesuatu ditentukan oleh pengalaman individu tersebut dengan objek yang dipersepsi. Dengan demikian persepsi lansia terhadap fasilitas publik di Kota Semarang merupakan hasil pengalaman lansia dalam mengakses fasilitas tersebut.

Fasilitas publik adalah semua atau sebagian dari kelengkapan prasarana dan sarana yang dapat digunakan atau dimanfaatkan oleh banyak orang, rakyat atau masyarakat umum (Echols \& Shadily, 2016; Permen PU No. 30 tahun 2006; Suharso \& Retnoningsih, 2011). Secara khusus Menteri Pekerjaan Umum, melalui Permen PU No. 30 Tahun 2006, mengatakan bahwa persyaratan teknis fasilitas dan aksesibilitas bangunan untuk fasilitas publik meliputi ukuran dasar bangunan, jalur pedestrian, jalur pemandu, area parkir, pintu, ram, tangga, lift, lift tangga, toilet, pancuran, wastafel, peralatan dan perlengkapan kontrol, perabot dan rambu-rambu lalu lintas. Disebutkan pula bahwa dalam membuat fasilitas publik harus memperhatikan keamanan, kemudahan, kegunaan dan kemandirian untuk semua orang, termasuk penyandang disabilitas dan 
lansia, baik untuk bangunan yang berfungsi sebagai hunian, keagamaan, usaha, sosial budaya, khusus dan umum.

Ketersediaan fasilitas publik yang ramah lansia merupakan bentuk dukungan masyarakat (pemerintah, swasta dan masyarakat pada umumnya) terhadap lansia, karena dapat memperlancar mobilitas lansia dalam keterbatasannya. Peraturan Menteri Sosial RI Nomor 19 tahun 2012 tentang Pedoman Pelayanan Sosial Lanjut Usia menyebutkan bahwa adalah tugas pemerintah, pemerintah daerah maupun masyarakat untuk menyediakan berbagai kemudahan untuk memperoleh dan menggunakan fasilitas pelayanan, sarana dan prasarana umum untuk mendukung dan mempelancar mobilitas lanjut usia. Tanpa adanya fasilitas publik yang ramah lansia maka para lansia akan kesulitan dalam memenuhi kebutuhan hidupnya seharihari dan cenderung menggantungkan diri kepada orang lain. Hal ini sesuai dengan pendapat Townsend (2008) bahwa masyarakat yang tidak peduli menciptakan dan menguatkan ketergantungan lansia.

Studi teoritis dan empiris dari beberapa perspektif menekankan pentingnya lansia untuk aktif secara fisik dan psikologis (Gagliardi dkk., 2007). Teori aktivitas mengatakan bahwa orang dapat menua dengan baik bila mereka dapat terus berpartisipasi dalam berbagai aktivitas sehari-hari yang bermanfaat. Sesuai dengan pembahasan di atas, maka bila lansia menilai bahwa fasilitas yang ada di lingkungan sekitar sungguh baik maka mereka akan bisa terus aktif. Tetapi dalam kenyataan sering dijumpai berbagai fasilitas publik di Kota Semarang yang dibuat atau diselenggarakan tanpa mempertimbangkan kebutuhan lansia, dan dengan demikian mengabaikan Peraturan Menteri Sosial RI Nomor 19 tahun 2012, yang pada gilirannya membuat lansia merasa kesulitan bahkan merasa tidak mampu mandiri dalam mengurus kebutuhannya. Teori model ekologi Lawton (dalam Gagliardi, 2007) mengatakan bahwa seringkali ada kesenjangan antara kebutuhan pribadi seseorang dengan konteks peluang yang ditemui di sekitarnya. Bila dikaitkan dengan lansia maka penglepasan (disengagement) pada lansia terjadi bukan karena keinginan intrinsik tetapi secara individual dimodulasi dan dipengaruhi oleh kesesuaian antara kebutuhan lansia dengan apa yang disediakan oleh lingkungannya. Lansia yang merasa tidak terpenuhi kebutuhannya di lingkungan akan cenderung menarik diri dan tidak aktif.

Dilihat dari hasil analisis data secara umum terhadap seluruh fasilitas publik di Kota Semarang, tanpa melihat per-aspeknya, nampak bahwa pandangan subjek bisa dikatakan berimbang antara yang mengatakan baik dan buruk (52\% vs $48 \%$ ). Bisa terjadi demikian karena sebagian besar subjek penelitian memberikan komentar positif maupun negatif terhadap fasilitas publik yang sama. Hal ini tidak mengherankan karena memang tiap fasilitas publik mengandung lebih dari satu point penilaian, sehingga bisa jadi satu point dinilai baik sedangkan point yang lain dinilai buruk.

Secara lebih khusus, hasil analisis data kuantitatif maupun kualitatif terhadap penilaian subjek tentang empat fasilitas publik di Kota Semarang menunjukkan bahwa subjek secara berturut-turut memiliki penilaian yang baik terhadap rumah sakit, gedung, transportasi umum dan jalan raya. Dengan demikian para lansia lebih banyak mengalami hal yang positif terkait dengan fasilitas yang ada di rumah sakit/fasilitas kesehatan lainnya dan gedung layanan publik, sedangkan persepsi atau penilaian negatif lebih banyak diberikan lansia pada jalan raya dan transportasi umum.

Aspek rumah sakit/fasilitas kesehatan lainnya merupakan aspek yang paling banyak dinilai positif oleh subjek. Analisis kuantitatif maupun kualitatif menunjukkan bahwa sebagian besar 
subjek penelitian mempersepsi bahwa fasilitas yang ada di rumah sakit atau fasilitas kesehatan lainnya sudah baik. Adapun sub-aspek dari rumah sakit yang paling dipersepsi baik adalah layanan informasi. Sementara itu sub-aspek pendaftaran, terutama pendaftaran online, paling banyak dikeluhkan.

Gedung layanan publik merupakan aspek yang berada pada peringkat kedua yang dinilai baik oleh subjek penelitian, sejumlah $84.9 \%$ subjek menganggap bahwa fasilitas yang ada di gedung layanan publik yang mereka kunjungi umumnya sudah baik. Hasil penelitian kuantitatif dan kualitatif sama-sama menunjukkan bahwa lokasi kantor merupakan sub-aspek yang paling dinilai baik. Bisa dipahami karena memang sebagian besar kantor layanan publik berada pada tempat yang baik dan mudah diakses. Sementara itu toilet dan papan petunjuk mendapatkan penilaian paling buruk.

Berkaitan dengan persepsi tentang jalan raya, subjek yang menilai positif lebih banyak daripada yang menilai negatif (63.2\% vs $36.8 \%)$.

Untuk aspek transportasi hasil analisis data menunjukkan bahwa bus trans lebih banyak dinilai baik oleh subjek dibandingkan dengan angkot . Kesulitan yang biasa dialami lansia terkait dengan transportasi massa yaitu naik turun tangga, menghindari pintu bus yang menutup otomatis, goncangan di dalam kendaraan, menunggu dalam cuaca yang kurang baik (hujan atau panas), perjalanan yang pelan/lama, berjalan jauh, dan ketakutan terhadap kejahatan di kendaraan. Berkaitan dengan hal tersebut angkot mendapatkn penilaian yang lebih buruk dibandingkan bus trans. Selanjutnya pada bus trans subaspek halte mendapatkan persentase penilaian negatif yang paling tinggi (11,11\%), sedangkan pada angkot yang dinilai paling negatif adalah perilaku sopir (13,89\%).

Kelemahan penelitian ini adalah fasilitas publik yang dipersepsi oleh subjek berbeda-beda. Selain itu penelitian ini tidak memerhatikan faktor pendidikan dan status sosial ekonomi subjek penelitian padahal Eun \& Lee (2013) mengatakan bahwa persepsi terhadap fasilitas publik ditentukan antara lain oleh tingkat pendidikan, pekerjaan dan penghasilan.

\section{SIMPULAN DAN SARAN}

Hasil analisis secara umum terhadap data persepsi tentang fasilitas publik di Kota Semarang, tanpa melihat per-aspeknya, menunjukkan bahwa pandangan subjek relatif berimbang antara yang mengatakan baik dan buruk (52\% vs $48 \%$ ). Secara lebih khusus, hasil analisis data kuantitatif maupun kualitatif terhadap penilaian subjek tentang empat fasilitas publik di Kota Semarang rumah sakit dinilai paling positif oleh subjek, terutama pada sub-aspek layanan informasi, sedangkan aspek jalan raya dipersepsi paling negatif.

Berdasarkan hasil penelitian dan pembahasan maka disarankan kepada pemerintah Kota Semarang untuk mewujudkan Kota Semarang sebagai kota yang ramah lansia sesuai dengan Peraturan Menteri Sosial RI Nomor 19 tahun 2012. Fasilitas publik yang berkaitan dengan jalan raya yang perlu diperbaiki dan ditambah adalah trotoar, sedangkan fasilitas transportasi yang perlu diperbaiki adalah perilaku sopir angkot dan halte bus trans. Untuk rumah sakit, pendaftaran online menjadi suatu aspek yang perlu mendapatkan perhatian khusus karena subjek penelitian melaporkan kesulitan untuk mengakses pendaftaran secara online. Penelitian selanjutnya hendaknya memberikan batasan yang jelas tentang aspek fasilitas publik yang dipersepsi subjek dan memerhatikan karakteristik demografis subjek (tingkat pendidikan, pekerjaan, penghasilan dst.) 


\section{DAFTAR PUSTAKA}

Bjorklund, B.R. \& Bee, H.L. (2009). The Journey of Adulthood. $6^{\text {th }}$ Edition. London: Pearce Education, LTD.

Echols, J.M \& Shadily, H. (2016). Kamus Inggris Indonesia: An EnglishIndonesia Dictionary. Jakarta: Penerbit PT Gramedia Pustaka Utama.

Eun, H-K \& Lee, J-H (2013). The impact of service quality of public sports facilities on citizens satisfaction, image, and word-of-mouth intention. The Sport Journal. Diakses dari https://www.printfriendly.com/p/g /v/vKyXEN

Fontana, A. \& Frey, J.H. (2009). Wawancara seni ilmu pengetahuan. Dalam Handbook of Qualitative Research. Editor Norman Denzin \& Yvonna, S. Lincoln. Edisi terjemahan oleh Daryatno, Badrus Samsul Fata, Abi, John Rinaldi. Yogyakarta: Penerbit Pustaka Pelajar.

Gagliardi, C., $\quad$ Spazzafumo, L., Marcellini, F., $\quad$ Mollenkopf, H., Ruoppila, I., Tacken, M. dan Sze'Mann, Z. (2007). The outdoor mobility and leisure activities of older people in five European countries. Journal of Ageing \& Society 27, 2007, 683-700. f2007 Cambridge University Press . doi:10.1017/S0144686X0700619 8

Haak, M., Fange, A., Iwarsson, S., dan Ivanoff, S.D. (2007). Home as a signification of independence and autonomy: Experiences among very old Swedish people.

Scandinavian Journal of Occupational Therapy. $14.16-24$. Doi:10.1080/11038120601024929
Hara, S. (2007). Managing the dyad between independence and dependence: Case studies of the American elderly and their lives with pets. International Journal of Japanese Sociology. Number 16. 100-114. doi: 10.1111/j.14756781.2007.00102.x

Johnson, R.B \& Turner, L.A (2010). Handbook of mixed methods in social \& behavioral research. Dalam Abbas Tashakkori \& Charles Teddlie (Eds.). Teknik Pengumpulan Data dalam Penelitian Metode Campuran. Diterjemahkan oleh Daryatno. Yogyakarta: Pustaka Pelajar

Kail, R.V \& Cavanaugh, J.C. (2013). Human Development: a Life-span View. International edition. Canada: Wadsworth Cengange Learning. Halaman 105-109.

National Population \& Familly Development. (2015). What the community can do to provide care for the elderly. A Voice for Senior: Seniors Aloud. Diakses dari Http://www. seniorsaloud.com/2015/05/whatcommunity-can-do-...

Papalia D.E., Sterns H.L., Feldman R.D dan Camp C.J. (2007). Adult Development and Aging. Third Edition. Boston: McGraw-Hill Companies, Inc.

Peraturan Menteri Pekerjaan Umum Nomor 30/PRT/M/2006 tentang Pedoman Teknik Fasilitas dan Aksesibilitas pada Bangunan Gedung dan Lingkungan. 
Peraturan Menteri Pekerjaan Umum Nomor 3/PRT/M/2014 tentang Pedoman Perencanaan, Penyediaan dan Pemanfaatan Prasarana dan Sarana Jaringan Pejalan Kaki di Kawasan PerkotaanPeraturan Menteri Sosial RI Nomor 19 tahun 2012 tentang Pedoman Pelayanan Sosial Lanjut UsiaRooy, G.V; Mufune, P dan Amadhila, E. (2015). Experiences and perceptions of barriers to health services for elderly in rural Namibia: A qualitative studi. SAGE Open Juli-September 2015.

Suharso \& Retnoningsih, A. (2011). Kamus Besar Bahasa Indonesia. Semarang: Penerbit Widya Karya.
Townsend, P. (2008)). The structured dependency of the elderly: A creation of social policy in the twentieth century. Journal of Ageing and Society, Volume $1 /$ Issue 01 / January 1981, pp 5 - 28. DOI:

10.1017/S0144686X81000020, Published online: 14 November 2008

Wijayanti, A. (2015). Ruang publik ramah lansia, ruang publik yang ramah untuk semua. Diakses dari http://www.kompasiana.com/afoa sri). Hal 1-12.

Williams, Y. (2017). Introduction to Psychology. Diakses dari Http:www.

studi.com/academic/lesson/whatis-in-peception) 2003-2017 pada tanggal 6 Nopember 2017. 